\title{
Determinan Struktur Modal dalam Upaya Meningkatkan Profitabilitas Perusahaan Manufaktur di Indonesia
}

\author{
Stefani Chandra ${ }^{1}$, Martha Ng. ${ }^{2}$, dan Evelyn Wijaya ${ }^{3 *)}$ \\ 1, 2, 3*) Institut Bisnis dan Teknologi Pelita Indonesia, Program Studi S1 Manajemen \\ Jl. Jendral Ahmad Yani No. 78-88, Pekanbaru, Riau, 28127 \\ Email: evelyn.wijaya@lecturer.pelitaindonesia.ac.id ${ }^{3 *}$
}

\begin{abstract}
ABSTRAK
Setiap perusahaan dalam menjalankan usahanya mempunyai tujuan yaitu untuk mencapai profit yang optimal. Profit mampu memberikan gambaran kinerja perusahaan dalam suatu periode serta menjadi daya tarik bagi investor dalam melakukan kegiatan jual beli saham. Perusahaan manufaktur merupakan salah satu perusahaan yang memberikan peranan penting bagi perekonomian nasional. Hal ini dapat terlihat dari laba perusahaan yang menunjukkan trend meningkat dibandingkan sektor lainnya. Penelitian ini bertujuan untuk menganalisis pengaruh ukuran perusahaan, uniqueness dan tangibilitas terhadap struktur modal dan profitabilitas pada perusahaan manufaktur. Populasi dalam penelitian adalah seluruh perusahaan manufaktur yang terdaftar di BEI periode 2010-2018 sebanyak 145 perusahaan. Sampel dalam penelitian sebanyak 96 perusahaan yang dipilih dengan menggunakan teknik purposive sampling. Teknik analisis data penelitian menggunakan bantuan program AMOS. Hasil penelitian menyatakan bahwa ukuran perusahaan dan tangibilitas tidak berpengaruh signifikan terhadap struktur modal, uniqueness berpengaruh signifikan positif terhadap struktur modal, dan struktur modal berpengaruh signifikan negatif terhadap profitabilitas. Hasil penelitian mendukung pecking order theory yang menyatakan bahwa semakin rendah nilai hutang perusahaan maka akan meningkatkan profitabilitas perusahaan.
\end{abstract}

Kata Kunci: Profitabilitas; Tangibilitas; Struktur Modal; Ukuran Perusahaan; Uniqueness

\begin{abstract}
Maximize profit has become one of the aims for companies in carrying their day to day operations. Profit reflects companies' performance within a certain period of time and also becomes attractiveness for investors in buying and selling shares. Manufacturing companies have become a sector which plays important part in the national economy. It is reflected from its rising profit compared to the other sectors. This research aims to analyze the effect of firm size, uniqueness, and tangibility on capital structure and profitability of manufacturing sector. The population in this research included all manufacturing companies listed on IDX for the period of 2010 to 2018 with the total of 117 companies. The samples consisted of 96 companies which were chosen using purposive sampling technique. Data analysis technique used was AMOS. The research results concluded that firm size and tangibility do not significantly affect capital structure, uniqueness has positive significant effect on capital structure, and capital structure has negative and significant effect on profitability. The results support the pecking order theory which stated that as companies' debts decrease, their profitability will rise.
\end{abstract}

Keywords: Profitability; Tangibility; Capital Structure; Firm Size; Uniqueness 


\section{PENDAHULUAN}

Perusahaan dalam menjalankan usahanya mempunyai tujuan yaitu menghasilkan keuntungan yang optimal dan meningkatkan kesejahteraan pemegang saham. Untuk mencapai tujuan tersebut perusahaan perlu memanfaatkan sumber daya yang ada dengan efektif dan efisien guna mencapai kinerja yang baik. Kinerja perusahaan dapat diukur melalui kemampuan perusahaan untuk menghasilkan laba dengan memanfaatkan modal dan asset yang dimiliki perusahaan. Keberhasilan perusahaan dilihat dari efektivitas kinerja manajemen dalam upaya memaksimalkan profit perusahaan melalui aktivitas bisnis yang dilakukan. Dari sudut pandang investor, salah satu indikator penting untuk menilai prospek perusahaan di masa datang adalah dengan melihat sejauh mana pertumbuhan profitabilitas perusahaan (Chandra et al., 2018).

Indonesia merupakan salah satu negara yang memiliki pertumbuhan ekonomi yang stabil dengan rata-rata sebesar 5\%-6\%. Kondisi ini mendorong minat investor untuk melakukan investasi di Indonesia dimana terbukti nilai investasi Indonesia baik investasi dalam negeri maupun investasi asing mengalami peningkatan setiap tahunnya. Pada tahun 2018, nilai investasi asing mengalami penurunan yang disebabkan karena gejolak nilai tukar Rupiah serta perang dagang yang terjadi antara Amerika Serikat dan China (www.bkpm.go.id). Kondisi investasi Indonesia ini menerangkan bahwa dengan pertumbuhan ekonomi Indonesia yang stabil akan menciptakan iklim investasi yang bagus dan memberikan peluang yang menggiurkan bagi investor.

Perusahaan manufaktur merupakan sektor yang memberikan kontribusi perekonomian yang cukup besar. Nilai manufacturing value added (MVA) Indonesia pada tahun 2018 mencapai 4,84\% sedangkan nilai MVA ASEAN yakni sebesar 4,5\% (www.kemenperin.go.id). Secara global perusahaan manufaktur di Indonesia berada di peringkat ke-9 dari seluruh negara di dunia. Berikut adalah data laba perusahaan manufaktur dalam beberapa tahun terakhir yang dapat dilihat pada gambar 1 .

Berdasarkan rujukan Gambar 1, terlihat bahwa laba perusahaan manufaktur memperlihatkan trend meningkat selama periode penelitian. Laba perusahaan manufaktur meningkat sebesar $88,02 \%$ dibandingkan dengan tahun 2010. Hal ini menjelaskan bahwa perusahaan manufaktur mampu menghasilkan kinerja keuangan yang cukup stabil setiap tahunnya. 


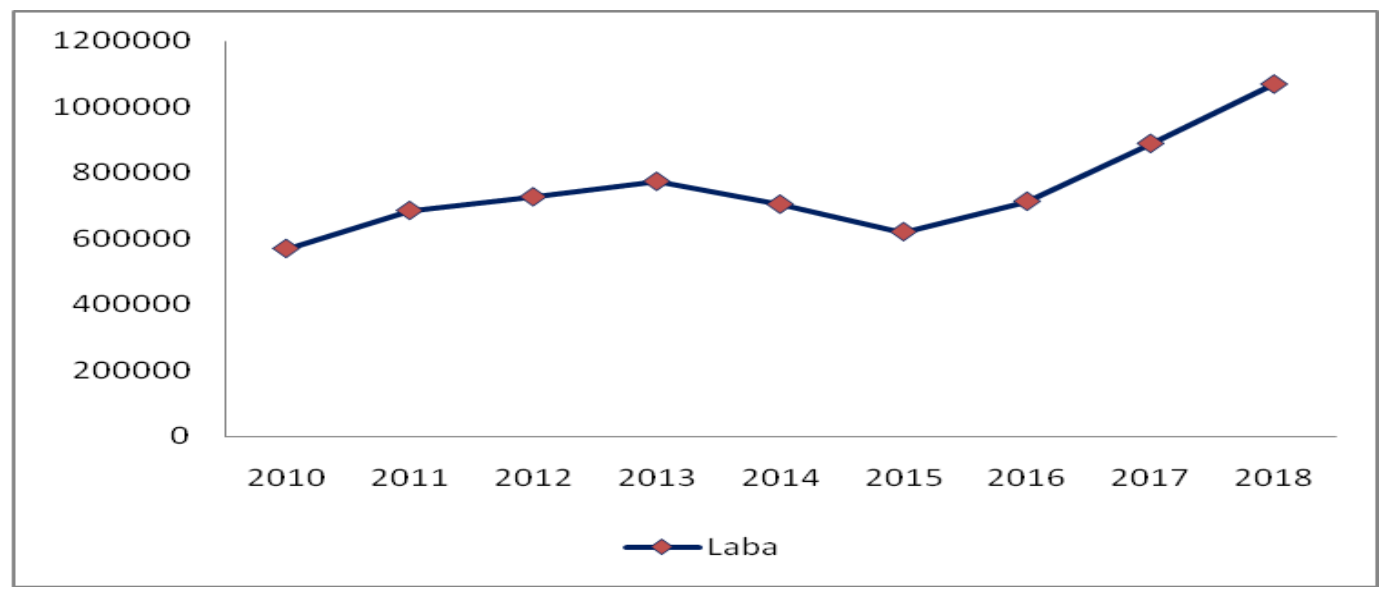

Gambar 1. Laba Perusahaan Manufaktur

Sumber: www.idx.co.id (diolah), 2020

Penelitian ini penting dilakukan mengingat bahwa penelitian mengenai uniqueness masih sangat jarang dilakukan di Indonesia. Salah satu kunci keberhasilan perusahaan manufaktur di pasar dapat dilihat dari keunikan produk maupun kebijakan serta strategi perusahaan manufaktur untuk menarik perhatian pasar dalam upaya menghasilkan profit yang optimal pada masa yang akan datang.

Teori pecking order menjelaskan mengapa perusahaan yang mempunyai tingkat keuntungan yang lebih tinggi justru mempunyai tingkat utang yang kecil. Pecking order theory menyatakan bahwa penggunaan hutang hanya dapat dilakukan apabila laba ditahan perusahaan sudah tidak mencukupi kebutuhan operasional perusahaan. Pecking order theory menyatakan perusahaan dengan tingkat profit yang tinggi cenderung memiliki hutang yang rendah. Hal ini dikarenakan profit yang dihasilkan perusahaan dapat digunakan untuk membiayai kegiatan operasional dan melunasi kewajiban kepada pihak ketiga. Dengan demikian struktur modal berpengaruh negatif terhadap profitabilitas. Pernyataan ini sejalan dengan penelitian (Akeem, et al., 2014; Chadha \& Sharma, 2015; Chandra, et al., 2019; Chen \& Chen, 2011; Salim \& Yadav, 2012) namun berbeda dengan penelitian (Al Ani \& Al Amri, 2015; Astuti \& Rosyid, 2015).

H1: struktur modal berpengaruh negatif terhadap profitabilitas perusahaan manufaktur

Ukuran perusahaan mencerminkan besar kecilnya suatu perusahaan yang dapat diukur melalui total asset maupun total penjualan. Perusahaan yang besar akan memiliki akses yang lebih mudah untuk memperoleh sumber dana eksternal dan memiliki kesempatan yang lebih besar untuk memenangkan persaingan serta bertahan dalam pasar industri dibandingkan dengan perusahaan yang kecil. Perusahaan besar mempunyai kemampuan untuk melakukan diversifikasi 
resiko sehingga resiko kebangkrutan menjadi lebih rendah. Rendahnya resiko kebangkrutan dapat dilihat melalui credit rating perusahaan yang lebih tinggi dibandingkan perusahaan kecil. Akhirnya, kondisi ini akan membuat perusahaan besar lebih berani dalam mengambil keputusan untuk menambah hutang. Pernyataan ini sejalan dengan penelitian (Al Ani \& Al Amri, 2015) yang menemukan ukuran perusahaan berpengaruh positif terhadap leverage pada sektor makanan di Muscat Securities Market. Hasil penelitian lainnya yang sejalan yakni penelitian yang dilakukan oleh (Chen et al., 2014; Cheng \& Tzeng, 2014; Lemma \& Negash, 2013; Thi Hang \& Jay Hung, 2016; Yang et al., 2010) namun berbeda dengan penelitian (Fauzi et al., 2013; Chandra et al., 2019; Tse \& Rodgers, 2014). (Salim \& Yadav, 2012) dalam penelitiannya menemukan ukuran perusahaan berpengaruh positif terhadap profitabilitas. Perusahaan yang besar akan cenderung menggunakan hutang untuk membiayai operasionalnya. Penggunaan hutang ini dimaksudkan untuk memanfaatkan tax deductive dari biaya bunga sehingga akan mendorong peningkatan profitabilitas. Dengan demikian semakin besar ukuran perusahaan maka profit yang dihasilkan akan semakin tinggi. Pernyataan ini sejalan dengan penelitian yang dilakukan oleh (Mirza \& Javed, 2013; Quang \& Xin, 2014) namun berbeda dengan penelitian (Chadha \& Sharma, 2015; Odusanya et al., 2018).

H2: ukuran perusahaan berpengaruh signifikan terhadap struktur modal pada perusahaan manufaktur

H3: ukuran perusahaan berpengaruh signifikan terhadap profitabilitas pada perusahaan manufaktur

Penelitian yang dilakukan oleh (Titman \& Wessels, 1988) menemukan adanya pengaruh negatif antara uniqueness dan struktur modal. Semakin unik produk atau kebijakan yang dihasilkan perusahaan maka perusahaan akan membutuhkan tenaga kerja dan supplier yang unik juga. Kondisi ini akan mendorong peningkatan resiko perusahaan dan mengakibatkan investor akan mempertimbangkan kembali permintaan hutang dari perusahaan. Dengan demikian dapat disimpulkan bahwa uniqueness berpengaruh negatif terhadap struktur modal. Penelitian lainnya yang dilakukan (Chang, et al., 2014; Taghavi et al., 2013; Yang et al., 2010) menemukan bahwa uniqueness tidak memberikan pengaruh yang signifikan terhadap struktur modal. Sementara, penelitian yang dilakukan oleh (Cheema \& Kaikati, 2010) menemukan bahwa uniqueness berpengaruh negatif signifikan terhadap profitabilitas. Hal ini menerangkan bahwa perusahaan yang menghasilkan produk atau kebijakan yang unik membutuhkan biaya yang lebih besar untuk 
kegiatan research \& development. Kondisi ini mampu menurunkan profit perusahaan.

H4: uniqueness berpengaruh signifikan terhadap struktur modal pada perusahaan manufaktur H5: uniqueness berpengaruh signifikan terhadap profitabilitas pada perusahaan manufaktur

Tangibilitas mencerminkan perimbangan antara asset tetap dan total asset (Riyanto, 2011). Perusahaan yang memiliki asset tetap yang lebih besar cenderung menggunakan hutang lebih besar karena asset tersebut dapat dijadikan sebagai jaminan hutang untuk memperoleh tambahan dana. Dengan demikian semakin besar asset tetap perusahaan maka nilai hutang akan meningkat. Pernyataan ini sejalan dengan penelitian yang dilakukan oleh (Fauzi, et al., 2013; Yang, et al., 2010) namun berbeda dengan penelitian (Chandra et al., 2019; Lemma \& Negash, 2013; Titman \& Wessels, 1988). Perusahaan yang memiliki tangibilitas yang besar dapat meminimalisir biaya keagenan yang akhirnya mampu mendorong peningkatan profitabilitas. Pernyataan ini sejalan dengan penelitian yang dilakukan oleh (Dawar, 2014) namun berbeda dengan penelitian (Chandra et al., 2019; Lazăr, 2016; Quang \& Xin, 2014).

H6: tangibilitas berpengaruh positif terhadap struktur modal pada perusahaan manufaktur

H7: tangibilitas berpengaruh positif terhadap profitabilitas pada perusahaan manufaktur

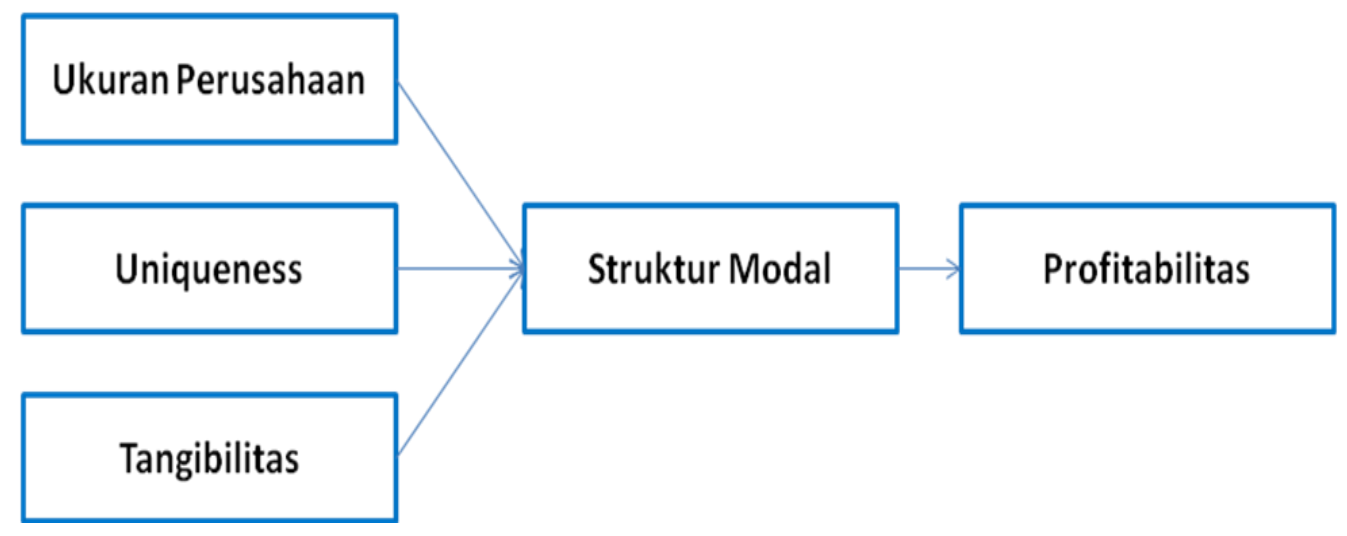

Gambar 2. Model Penelitian

Sumber : (Chandra et al., 2019; Lemma \& Negash, 2013; Titman \& Wessels, 1988; Yang et al., 2010)

\section{METODE PENELITIAN}

Penelitian ini dilakukan pada perusahaan sektor manufaktur yang terdaftar di Bursa Efek Indonesia (BEI) dengan rentang waktu penelitian periode 2010 sampai dengan 2018. Penelitian dilakukan mulai dari pengajuan hibah PDP tahun 2019 sampai dengan tahun pelaksanaan penelitian 2020 . 
Populasi penelitian adalah seluruh perusahaan manufaktur terdaftar di Bursa Efek Indonesia (BEI) sebanyak 145 perusahaan periode 2010-2018. Sampel yang digunakan dalam penelitian sebanyak 96 perusahaan yang diseleksi dengan menggunakan teknik purposive sampling. Adapun kriteria pemilihan sampel yakni (1) perusahaan yang IPO di BEI sebelum tahun 2010, (2) perusahaan yang tidak di suspend oleh BEI selama periode pengamatan, (3) perusahaan yang tidak di delisting oleh BEI selama periode pengamatan, dan (4) perusahaan yang melakukan kegiatan research \& development.

Penelitian ini terdiri dari variabel eksogen yakni ukuran perusahaan $\left(\mathrm{X}_{1}\right)$, uniqueness $\left(\mathrm{X}_{2}\right)$, tangibilitas $\left(\mathrm{X}_{3}\right)$ dan variabel endogen yakni struktur modal $\left(\mathrm{Y}_{1}\right)$ dan profitabilitas $\left(\mathrm{Y}_{2}\right)$.

\section{Tabel 1. Operasional Variabel Penelitian}

\begin{tabular}{|c|c|c|c|}
\hline Variabel & Nama Variabel & Rumus & Sumber Peneliti \\
\hline \multirow[t]{2}{*}{ Y1 } & Struktur Modal & Variabel Endogen & \\
\hline & Total Debt & $\begin{array}{l}\text { Total Hutang/Total } \\
\text { Ekuitas }\end{array}$ & $\begin{array}{l}\text { (Akeem et al., 2014; Chandra, 2015; 2013; } \\
\text { Khan et al., 2013; Mirza \& Javed, 2013; } \\
\text { Quang \& Xin, 2014) }\end{array}$ \\
\hline \multirow[t]{2}{*}{ Y2 } & Profitabilitas & Variabel Endogen & \\
\hline & Return On Asset & Laba Bersih/Total Asset & $\begin{array}{l}\text { (Akeem et al., 2014; Al Ani \& Al Amri, 2015; } \\
\text { Quang \& Xin, 2014; Salim \& Yadav, 2012) }\end{array}$ \\
\hline \multirow[t]{2}{*}{$\mathrm{X} 1$} & Ukuran Perusahaan & Variabel Eksogen & \\
\hline & Total Asset & $\begin{array}{l}\text { Logaritma Natural Total } \\
\text { Asset }\end{array}$ & $\begin{array}{l}\text { (Al Ani \& Al Amri, 2015; Quang \& Xin, } \\
\text { 2014) }\end{array}$ \\
\hline \multirow[t]{3}{*}{$\mathrm{X} 2$} & Uniqueness & Variabel Eksogen & \\
\hline & Research & Biaya Penelitian dan & (Titman \& Wessels, 1988; Yang et al., 2010) \\
\hline & Development & $\begin{array}{l}\text { Pengembangan/ Total } \\
\text { Penjualan }\end{array}$ & \\
\hline \multirow[t]{2}{*}{$\mathrm{X} 3$} & Tangibilitas & Variabel Eksogen & \\
\hline & $F A$ & Asset Tetap/Total Asset & (Chandra et al., 2019; Yang et al, 2010) \\
\hline
\end{tabular}

Teknik pengumpulan data dengan cara mengunjungi website Bursa Efek Indonesia melalui situs www.idx.co.id, www.yahoofinance.com. Teknik pengumpulan data selanjutnya melalui studi pustaka dengan cara mengutip buku-buku, jurnal, artikel, media masa, dan jurnal terdahulu yang berhubungan dengan penelitian yang dilakukan. 
Teknik analisa data yang digunakan dalam penelitian adalah analisa jalur dengan menggunakan bantuan program statistik AMOS yaitu uji statistik deskriptif, uji asumsi klasik dan uji hipotesis penelitian.

\section{HASIL DAN PEMBAHASAN}

\section{Statistik Deskriptif}

(Sugiyono, 2012:147) analisis deskriptif digunakan untuk mengalisis data dengan cara mendeskripsikan atau menggambarkan data yang telah terkumpul sebagaimana adanya tanpa bermaksud membuat kesimpulan yang berlaku untuk umum atau generalisasi.

Tabel 2. Statistik Deskriptif

\begin{tabular}{lcccc}
\hline & Mean & Minimum & Maximum & Standar Deviasi \\
\hline Capital Structure & 1.0477 & -225.0049 & 162.1845 & 12.9457 \\
Profitability & 0.1033 & -9.6436 & 24.7160 & 1.0247 \\
Firm Size & 14.5601 & 11.2670 & 19.6582 & 1.6102 \\
Uniqueness & 0.0087 & 0.00001 & 0.9962 & 0.0523 \\
Tangibility & 0.3864 & 0.0010 & 0.9868 & 0.2121 \\
\hline
\end{tabular}

Adapun penjelasan tabel statistik deskriptif variabel penelitian eksogen dan endogen dapat dijelaskan sebagai berikut:

\section{Capital Structure (Y1)}

Rata-rata keseluruhan nilai capital structure perusahaan manufaktur dari tahun 2010 sampai dengan tahun 2018 sebesar 1.0477 kali (104,77\%) dengan nilai standar deviasi sebesar 12.9457. Nilai capital structure tertinggi terdapat pada perusahaan PT. Eterindo Wahanatama Tbk. (ETWA) tahun 2016 sebesar 162.1845 kali. Pada tahun 2016 nilai hutang perusahaan sebesar Rp 1.151,834 miliar sementara di sisi lain nilai ekuitas perusahaan hanya sebesar Rp 7,102 miliar. Dengan demikian nilai hutang perusahaan jauh melebihi nilai ekuitas perusahaan. Nilai capital structure terendah terdapat pada perusahaan PT. Sekawan Intipratama Tbk. (SIAP) tahun 2016 sebesar -225.0049 kali. Pada tahun 2016 nilai hutang perusahaan sebesar Rp 229,73 miliar sementara di sisi lain nilai ekuitas perusahaan bernilai negatif sebesar Rp 1.021 miliar. Dengan demikian nilai ekuitas perusahaan tidak mampu menutupi nilai hutang perusahaan. 


\section{Jmk}

\section{Profitability (Y2)}

Rata-rata keseluruhan nilai profitability perusahaan manufaktur dari tahun 2010 sampai dengan tahun 2018 sebesar 0.1033 kali (10,33\%) dengan nilai standar deviasi sebesar 1.0247. Nilai profitability tertinggi terdapat pada perusahaan PT. Sekawan Intipratama Tbk. (SIAP) tahun 2016 sebesar 24.7160 kali. Pada tahun 2016 perusahaan mengalami rugi bersih sebesar 25,235 miliar sementara di sisi lain nilai ekuitas perusahaan bernilai negatif sebesar Rp 1.021 miliar. Ini menjelaskan bahwa tingginya nilai return on equity dikarenakan perusahaan mengalami rugi bersih yang diikuti dengan nilai ekuitas perusahaan bernilai negatif. Nilai profitability terendah terdapat pada perusahaan PT. Eterindo Wahanatama Tbk. (ETWA) tahun 2016 sebesar -9.6436 kali. Pada tahun 2016 nilai ekuitas perusahaan sebesar Rp 7,102 miliar sementara di sisi lain perusahaan mengalami rugi bersih sebesar Rp 68,489 miliar. Hal ini menjelaskan bahwa perusahaan belum mampu memanfaatkan ekuitas perusahaan yang dimiliki untuk menghasilkan laba.

\section{Firm Size (X1)}

Rata-rata keseluruhan nilai firm size perusahaan manufaktur dari tahun 2010 sampai dengan tahun 2018 sebesar 14.5601 kali dengan nilai standar deviasi sebesar 1.6102. Nilai firm size tertinggi terdapat pada perusahaan PT. Astra International Tbk. (ASII) tahun 2018 sebesar 19.6582 kali. Pada tahun 2018, nilai asset perusahaan mencapai Rp 344.771 miliar yang mengalami peningkatan sebesar 16,52\% dibandingkan dengan tahun sebelumnya. Nilai firm size terendah terdapat pada perusahaan PT. Lion Mesh Prima Tbk. (LMSH) tahun 2010 sebesar 11.2670 kali. Pada tahun 2010, terjadi penurunan nilai asset tidak lancar akibat terjadi penambahan akumulasi penyusutan sebesar Rp 1,62 miliar.

\section{Uniqueness (X2)}

Rata-rata keseluruhan nilai uniqueness perusahaan manufaktur dari tahun 2010 sampai dengan tahun 2018 sebesar 0.0087 kali dengan nilai standar deviasi sebesar 0.0523. Nilai uniqueness tertinggi terdapat pada perusahaan PT. Intikeramik Alamsari Industri Tbk. (IKAI) tahun 2018 sebesar 0.9962 kali. Biaya research \& development sebesar Rp 11,23 miliar sedangkan nilai pendapatan sebesar Rp 11,28 miliar. Dengan demikian kegiatan research \& development belum mampu mendorong peningkatan pendapatan perusahaan. Nilai uniqueness terendah terdapat pada perusahaan PT. Indomobil Sukses International Tbk. (IMAS) sebesar 0.00001 kali. Kegiatan research \& development yang dilakukan oleh perusahaan mengarah pada 
pengembangan jaringan pemasaran produk dan jasa. Dengan demikian kegiatan research \& development mampu mendorong peningkatan pendapatan perusahaan.

\section{Tangibility (X3)}

Rata-rata keseluruhan nilai tangibility perusahaan manufaktur dari tahun 2010 sampai dengan tahun 2018 sebesar 0.3864 kali dengan standar deviasi sebesar 0.2121 . Nilai tangibility tertinggi terdapat pada perusahaan PT. Budi Starch \& Sweetener Tbk. (BUDI) tahun 2013 sebesar 0.9868 kali. Nilai asset tetap perusahaan sebesar Rp 1.271,81 miliar sementara di sisi lain nilai asset perusahaan sebesar Rp 1.288,8 miliar. Dengan demikian sebagian besar asset perusahaan berasal dari asset tetap. Nilai tangibility terendah terdapat pada perusahaan PT. Gunawan Dianjaya Steel Tbk. (GDST) sebesar 0.0010 kali tahun 2013. Nilai asset tetap perusahaan sebesar Rp 1,24 miliar sementara di sisi lain nilai asset perusahaan sebesar Rp 1.191,5 miliar. Dengan demikian sebagian besar asset perusahaan berasal dari asset lancar.

\section{Uji Asumsi Klasik}

Multikolinearitas dapat dideteksi melalui diagram korelasi antar konstruk eksogen untuk mendeteksi tinggi rendahnya nilai korelasi konstruk. Jika korelasi antar variabel eksogen tinggi maka model perlu dipertimbangkan kembali. Dalam penelitian ini, multikolinearitas dilakukan dengan melihat apakah nilai determinan matriks kovariansi sampel jauh dari nilai nol atau tidak. Berikut adalah hasil uji multikolinearitas variabel penelitian yang diperoleh

Tabel 3. Uji Sample Covariance

\begin{tabular}{llllll}
\hline & FS & UNIQ & TANG & DER & ROE \\
\hline FS & 3.070 & & & & \\
UNIQ & 0.087 & 0.020 & & & \\
TANG & 0.000 & 0.000 & 0.000 & & \\
DER & 0.089 & 0.001 & 0.000 & 0.117 & 0.900 \\
ROE & 0.476 & 0.050 & 0.000 & -0.002 & \\
\hline
\end{tabular}

Determinant of sample covariance matrix $=0.000$

Berdasarkan informasi yang disampaikan dalam Tabel 3 memperlihatkan nilai determinan matriks kovarian sebesar 0.000. Hal ini mengindikasikan bahwa data penelitian bebas memiliki masalah multikolinearitas. Namun, pendapat lain menyatakan bahwa apabila nilai korelasi variabel penelitian kurang dari 0.9 maka mengindikasikan bahwa variabel penelitian tidak 
memiliki gejala multikolinearitas yang berat (Ghozali 2011:100).

Tabel 4. Uji Sample Correlations

\begin{tabular}{cccccc}
\hline & FS & UNIQ & TANG & DER & ROE \\
\hline FS & 1.000 & & & & \\
UNIQ & 0.347 & 1.000 & & & \\
TANG & -0.252 & 0.228 & 1.000 & 1.000 & \\
DER & 0.149 & 0.010 & 0.095 & -0.006 & 1.000 \\
ROE & 0.287 & 0.368 & -0.155 & & \\
\hline
\end{tabular}

Berdasarkan informasi yang disampaikan dalam Tabel 4 memperlihatkan nilai korelasi antar variabel penelitian memiliki nilai korelasi kurang dari 0.9. Hal ini mengindikasikan bahwa data penelitian tidak memiliki gejala multikolinearitas yang berat dan data penelitian layak untuk digunakan.

\section{Uji Hipotesis}

Hasil pengujian hipotesis dapat digunakan untuk mengetahui pengaruh antara variabel endogen dan variabel eksogen secara parsial.

\section{Tabel 5. Uji Hipotesis}

\begin{tabular}{lcccc}
\hline Variabel Endogen & Variabel Eksogen & Estimasi Parameter & T Hitung & P Value \\
\hline Struktur Modal & Ukuran Perusahaan & -0.003 & -0.290 & 0.772 \\
& Uniqueness & 0.650 & 1.944 & $* * *$ \\
& Tangibilitas & 0.089 & 1.060 & 0.289 \\
\hline Profitabilitas & Struktur Modal & -0.070 & -9.781 & $* * *$ \\
\hline
\end{tabular}

Adapun hasil pengujian hipotesis variabel penelitian dapat dijelaskan sebagai berikut :

1. Hasil uji analisa jalur memperlihatkan nilai koefisien beta hubungan antara ukuran perusahaan dan struktur modal sebesar -0.003. Hasil uji t hitung yang diperoleh sebesar 0.290. Hal ini menunjukkan bahwa ukuran perusahaan tidak berpengaruh signifikan terhadap struktur modal pada perusahaan manufaktur.

2. Hasil uji analisa jalur memperlihatkan nilai koefisien beta hubungan antara uniqueness dan struktur modal sebesar 0.650. Hasil uji t hitung yang diperoleh sebesar 1.944. Hal ini menunjukkan bahwa uniqueness berpengaruh signifikan positif terhadap struktur modal pada perusahaan manufaktur. 
3. Hasil uji analisa jalur memperlihatkan nilai koefisien beta hubungan antara tangibilitas dan struktur modal sebesar 0.089. Hasil uji t hitung yang diperoleh sebesar 1.060. Hal ini menunjukkan bahwa tangibilitas tidak berpengaruh signifikan terhadap struktur modal pada perusahaan manufaktur.

4. Hasil uji analisa jalur memperlihatkan nilai koefisien beta hubungan antara struktur modal dan profitabilitas sebesar -0.070. Hasil uji t hitung yang diperoleh sebesar -9.781. Hal ini menunjukkan bahwa struktur modal berpengaruh signifikan negatif terhadap profitabilitas pada perusahaan manufaktur.

Ukuran perusahaan mencerminkan besar kecilnya suatu perusahaan yang dilihat melalui total asset yang dimiliki oleh perusahaan. Semakin besar perusahaan maka hutang perusahaan akan semakin besar. Hal ini dikarenakan perusahaan besar membutuhkan dana yang cukup besar untuk membiayai kegiatan operasional perusahaan dimana dana internal perusahaan tidak mampu mencukupi kebutuhan perusahaan. Oleh karena itu, untuk memenuhi kebutuhan operasional maka perusahaan memerlukan tambahan dana yang berasal dari hutang. Pernyataan ini tidak sejalan dengan hasil pengujian hipotesis yang menyatakan bahwa ukuran perusahaan tidak berpengaruh signifikan terhadap struktur modal. Hal ini berarti bahwa besar kecilnya perusahaan tidak memberikan dampak pada nilai hutang. Perusahaan manufaktur yang sudah go public membutuhkan dana yang cukup besar untuk memenuhi kebutuhan operasional perusahaan dan menjual kepemilikan saham kepada investor. Pernyataan ini sejalan dengan penelitian (Chandra et al., 2019; Ahmad et al., 2013) namun berbeda dengan penelitian (Chen et al., 2014; Cheng \& Tzeng, 2014; Lemma \& Negash, 2013; Thi Hang \& Jay Hung, 2016; Yang et al., 2010).

Uniqueness mencerminkan produk atau kebijakan baru yang dihasilkan oleh perusahaan yang berbeda dengan produk pesaing (Titman \& Wessels, 1988). Untuk dapat menciptakan sesuatu yang unik, perusahaan membutuhkan adanya kegiatan penelitian dan pengembangan secara berkala. Kondisi ini mendorong perusahaan harus mengeluarkan biaya yang besar dan menghadapi resiko yang tinggi. Dengan demikian semakin unik produk atau kebijakan baru perusahaan maka hutang perusahaan akan semakin rendah. Perusahaan lebih memilih menggunakan dana internal untuk pembiayaan kegiatan research \& development dibandingkan dana eksternal. Pernyataan ini tidak sejalan dengan hasil pengujian hipotesis yang menyatakan bahwa uniqueness berpengaruh signifikan positif terhadap struktur modal. Hal ini menjelaskan bahwa semakin unik produk atau kebijakan perusahaan maka akan meningkatkan hutang 
perusahaan. Perusahaan manufaktur merupakan perusahaan yang produktif dimana perusahaan secara berkala perlu menciptakan kebaharuan guna mendongkrak penjualan. Kondisi ini mendorong perusahaan tidak dapat hanya mengandalkan dana internal tetapi perusahaan membutuhkan tambahan dana yang berasal dari hutang. Hasil penelitian ini tidak sejalan dengan penelitian (Chang et al., 2014; Chandra et al., 2019; Taghavi et al., 2013; Titman \& Wessels, 1998; Yang et al., 2010)

Tangibilitas mencerminkan sebagian asset perusahaan yang dapat dijadikan sebagai jaminan apabila perusahaan mengajukan permintaan dana kepada pihak ketiga. Perusahaan yang memiliki tangibilitas yang besar pada umumnya lebih mudah mendapatkan hutang karena perusahaan memiliki asset tetap yang besar (asset tetap dapat digunakan sebagai jaminan atas hutang). Dengan demikian semakin besar tangibilitas perusahaan maka kreditur akan lebih mudah memberikan pinjaman sehingga hutang perusahaan akan meningkat. Pernyataan ini tidak sejalan dengan hasil pengujian hipotesis yang menyatakan bahwa tangbilitas tidak berpengaruh signifikan terhadap struktur modal perusahaan manufaktur. Banyak sedikitnya asset tetap yang dapat dijadikan sebagai jaminan tidak memberikan dampak pada nilai hutang. Hasil penelitian ini sejalan dengan penelitian (Lemma \& Negash, 2013; Titman \& Wessels, 1988) namun berbeda dengan penelitian (Fauzi et al., 2013; Ramjee \& Gwatidzo, 2012; Thi Hang \& Jay Hung, 2016; Yang et al., 2010).

Hasil uji hipotesis menyatakan bahwa struktur modal berpengaruh signifikan negatif terhadap profitabilitas pada perusahaan manufaktur. Hasil penelitian ini sejalan dengan penelitian yang dilakukan oleh (Akeem et al., 2014; Chadha \& Sharma, 2015; Quang \& Xin, 2014; Salim \& Yadav, 2012) namun berbeda dengan penelitian (Al Ani \& Al Amri, 2015; Tse \& Rodgers, 2014). Semakin rendah hutang perusahaan maka akan meningkatkan profitabilitas perusahaan. Sektor manufaktur merupakan salah satu sektor yang memberikan pengaruh cukup besar terhadap perekonomian nasional dan sektor yang memiliki tingkat pertumbuhan usaha yang stabil dibandingkan dengan sektor lainnya. Dengan kondisi demikian, perusahaan manufaktur seharusnya dapat memanfaatkan dana internal yang berasal dari asset maupun penjualan untuk pemenuhan kegiatan operasional sedangkan dana eksternal berfungsi sebagai pelengkap.

\section{KESIMPULAN DAN SARAN}

Perusahaan manufaktur memegang peranan yang cukup penting dalam perekonomian nasional dan memberikan sumbangan yang cukup besar terhadap PDB suatu negara. Produk yang 
dihasilkan oleh perusahaan manufaktur digunakan untuk memenuhi kebutuhan masyarakat suatu negara. Dengan kondisi demikian mendorong perusahaan manufaktur berlomba-lomba untuk menghasilkan produk yang mampu memenuhi kebutuhan dan keinginan masyarakat. Untuk mencapainya, perusahaan tidak hanya dapat mengandalkan sumber dana internal perusahaan saja namun perusahaan memerlukan adanya tambahan dana yang berasal dari hutang. Namun, dalam hal ini perusahaan perlu menjaga tingkat hutang untuk meminimalisir terjadinya penurunan profit perusahaan secara signifikan.

Penelitian yang dilakukan saat ini hanya sebatas pada penggunaan variabel tangible perusahaan sehingga hasil yang diperoleh masih belum sempurna. Untuk penelitian selanjutnya diharapkan dapat melibatkan variabel keuangan lainnya untuk mendeteksi faktor-faktor yang dapat mempengaruhi struktur modal dan profitabilitas perusahaan. Penelitian ini juga diharapkan memberikan kontribusi bagi bidang manajemen keuangan terkait dengan faktor-faktor yang dapat mempengaruhi perubahan nilai struktur modal dan profitabilitas perusahaan dalam upaya memaksimumkan nilai perusahaan pada masa yang akan datang.

\section{REFERENSI}

Akeem, L. B., K, E. T., Kiyanjui, M. W., \& Kayode, A. M. (2014). Effects of Capital Structure on Firm's Performance: Empirical Study of Manufacturing Companies in Nigeria. 3(4), 3957.

Al Ani, M., \& Al Amri, M. (2015). The Determinants of Capital Structure: an Empirical Study of Omani Listed Industrial Companies. Verslas: Teorija Ir Praktika, 16(2), 159-167. https://doi.org/10.3846/btp.2015.471

Astuti, K. D., Retnowati, W., \& Rosyid, A. (2015). Pengaruh Struktur Modal terhadap Profitabilitas (Studi pada Perusahaan Go Publik yang menjadi 100 Perusahaan Terbaik Versi Majalah Fortune Indonesia Periode Tahun 2010-2012 ). Jurnal Akuntansi, 2(2339-2436), 49-60.

Chadha, S., \& Sharma, A. K. (2015). Capital Structure and Firm Performance: Empirical Evidence from India. Vision: The Journal of Business Perspective, 19(4), 295-302. https://doi.org/10.1177/0972262915610852

Chandra, Teddy, Junaedi, A. T., Wijaya, E., Chandra, S., \& Priyono. (2019). The CoDeterminant of Capital Structure and Profitability Based on the Supply Chain Strategy: Evidence from Manufacturing Sector in Indonesia. International Journal of Supply Chain Management, 8(6), 705-717.

Chang, C., Chen, X., \& Liao, G. (2014). What are the Reliably Important Determinants of Capital Structure in China? Pacific Basin Finance Journal, 30, 87-113. https://doi.org/10.1016/j.pacfin.2014.06.001

Cheema, A., \& Kaikati, A. M. (2010). The Effect of Need for Uniqueness on Word of Mouth. Journal of Marketing Research, 47(3), 553-563. https://doi.org/10.1509/jmkr.47.3.553 
Chen, L. J., \& Chen, S. Y. (2011). The Influence of Profitability on Firm Value with Capital Structure as the Mediator and Firm Size and Industry as Moderators. Investment Management and Financial Innovations, 8(3), 121-129. https://doi.org/10.1002/rhc3.12043

Chen, J., Jiang, C., \& Lin, Y. (2014). What Determine Firms' Capital Structure in China? Managerial Finance, 40(10), 1024-1039. https://doi.org/10.1108/MF-06-2013-0163

Cheng, M.-C., \& Tzeng, Z.-C. (2014). Effect of Leverage on Firm Market Value and How The Firm Financial Quality Influence on This Effect. Review of Pacific Basin Financial Markets and Policies, 17(01), 1450004. https://doi.org/10.1142/S0219091514500040

Fauzi, F., Basyith, A., \& Idris, M. (2013). The Determinants of Capital Structure: An Empirical Study of New Zealand-Listed Firms. Asian Journal of Finance \& Accounting, 5(2), 1. https://doi.org/10.5296/ajfa.v5i2.3740

Lazăr, S. (2016). Determinants of Firm Performance: Evidence from Romanian Listed Companies. Review of Economic and Business Studies, 9(1), 53-69. https://doi.org/10.1515/rebs-2016-0025

Lemma, T. T., \& Negash, M. (2013). Institutional, Macroeconomic and Firm-Specific Determinants of Capital Structure: The African Evidence. In Management Research Review (Vol. 36). https://doi.org/10.1108/MRR-09-2012-0201

Mirza, S. A., \& Javed, A. (2013). Determinants of Financial Performance of a Firm: Case of Pakistani Stock Market. Journal of Economics and International Finance, 5(2), 43-52. https://doi.org/10.5897/JEIF12.043

Odusanya, A. I., Yinusa, O. G., \& Ilo, B. M. (2018). Determinants of Firm Profitability in Nigeria: Evidence from Dynamic Panel Models. SPOUDAI, Journal of Economics and Business, 68(1), 43-58. Retrieved from https://www.researchgate.net/publication/325049840_Determinants_of_Firm_Profitability_i n_Nigeria_Evidence_from_Dynamic_Panel_Models

Quang, D. X., \& Xin, W. Z. (2014). The Impact of Ownership Structure and Capital Structure on Financial Performance of Vietnamese Firms. International Business Research, 7(2), 64-71. https://doi.org/10.5539/ibr.v7n2p64

Ramjee, A., \& Gwatidzo, T. (2012). Dynamics in Capital Structure Determinants in South Africa. Meditari Accountancy Research, 20 (1), 52-67.

Salim, M., \& Yadav, R. (2012). Capital Structure and Firm Performance: Evidence from Malaysian Listed Companies. Procedia - Social and Behavioral Sciences, 65(ICIBSoS), 156-166. https://doi.org/10.1016/j.sbspro.2012.11.105

Sheikh, N. A., \& Wang, Z. (2011). Determinants of Capital Structure of Leasing Companies in Pakistan. Applied Financial Economics, 22(1), 1841-1853.

Sugiyono. (2012). Metode Penelitian Pendidikan (Pendekatan Kualitatif, Kualitatif dan R\&D). Bandung: Alfabeta.

Taghavi, M., Khodaei Valahzaghard, M., \& Alishahi, M. (2013). Co-Determination of Capital Structure and Stock Returns in Banking Industry using Structural Equation Modeling. Management Science Letters, 3, 2367-2372. https://doi.org/10.5267/j.msl.2013.07.001

Thi Hang, N., \& Jay Hung, R. (2016). Determinants of Capital Structure of the Listed Companies on Vietnam Stock Market. The International Journal of Business \& Management, 4(6), 2735 .

Titman, S., \& Wessels, R. (1988). The Determinants of Capital Structure Choice. The Journal of Finance, 43(1), 1-19. https://doi.org/10.1111/j.1540-6261.1988.tb02585.x

Tse, C. B., \& Rodgers, T. (2014). The Capital Structure of Chinese Listed Firms: Is Manufacturing Industry Special? Managerial Finance, 40(5), 469-486. 
https://doi.org/10.1108/MF-08-2013-0211

Yang, C. C., Lee, C. few, Gu, Y. X., \& Lee, Y. W. (2010). Co-Determination of Capital Structure and Stock Returns-A LISREL approach. An Empirical Test of Taiwan Stock Markets. Quarterly Review of Economics and Finance, 50(2), 222-233. https://doi.org/10.1016/j.qref.2009.12.001

www.idx.co.id (di akses pada tanggal 28 April 2020) 